\title{
EFFECT OF CULTIVATION MEASURES ON INDEX OF PHOTOSYNTHESIS AND YIELD OF SUNFLOWER
}

\author{
Aksyonov, I. \\ Institute of Oilseed Crops, Ukrainian Academy of Agricultural Science, \\ Vesennyaya 1, Solnechniy, Zaporozhie 70417, Ukraine
}

Received: May 25, 2006 Accepted: September 15, 2007

SUMMARY

Photosynthetic activity is the decisive factor of yield increase in sunflower plants. This activity determines the application of agrotechnical measures such as row spacing and plant density. Experiments have proved that agrotechnical measures allow to control the growth, development and yield of sunflower hybrids and varieties. Row spacing and plants density affect the index of photosynthesis and the yield of sunflower agrophytocoenoses. Cultivation of sunflower at the row spacing of $15 \mathrm{~cm}$ in different variants of plants density increased the yield of the hybrid Zaporozhskiy 9 by $0.11-0.70 \mathrm{t} / \mathrm{ha}$, of the hybrid Kharkovskiy 58 by $0.62-1.1$ t/ha, of the variety Lider by $0.24-0.59 \mathrm{t} / \mathrm{ha}$, of the variety Prometey by $0.20-0.63$ t/ha as compared with the cultivation in agrophytocoenoces at the row spacing of $70 \mathrm{~cm}$.

Key words: sunflower, row spacing, density of plants, photosynthesis indexes, yield

\section{INTRODUCTION}

Modern sunflower hybrids and varieties have high yielding potentials, ranging within the limits of 4.0-6.0 t/ha (hybrids) and 2.5-3.5 t/ha (varieties). Nevertheless, these potential are realized in typical agrophytocoenoces with $50-60 \%$ and less.

Realization of genetic productivity of hybrids and varieties depends on cultivation conditions, biological features of genotypes and the activity of plant photosynthesising apparatus (Nettevich, 1986; Zhuchenko, 1990). Photosynthetic activity is the basis for productivity and yield level of agricultural crops. Agrotechnical measures should be aimed at increasing the photosynthetic efficiency through increased leaf area formation (Gulyaev, 1988; Demolon, 1970).

Net photosynthesis is the basic index of plant photosynthetic activity. Plant photosynthetic apparatus provides dry matter needed for the development of generative

* Corresponding autor: Phone/Fax: ++380 612597 780;

e-mail: aksyonov-igor@list.ru 
organs and enables high productivity of agrophytocoenoses (Vasilev, 1990; Dyakov, Perestova, 1975; Redko, 1985).

It appeared possible to increase the yield of sunflower by strengthening the photosynthetic activity of hybrids and varieties by means of agrotehnical methods (Bykov, Zeleskiy, 1982; Zhuchenko, 1988). Optimization of the structure of the sunflower agrophytocoenosis (plant arrangement and density) may help in solving this problem.

The purpose of this investigation was:

- to evaluate the effect of row distance and plant density on photosynthesis index of sunflower hybrids and varieties;

- to evaluate the effect of agrotehnical methods on sunflower yield;

- to determine the relationship between the index of photosynthesis and agrophytocoenotic yield of sunflower hybrids and varieties;

- to establish a sunflower agrophytocoenosis capable of ensuring a high level of photosynthesis and high yield of sunflower hybrids and varieties.

\section{MATERIAL AND METHODS}

An experiment has been conducted at Institute of Oilseed Crops (Zaporozhie, Ukraine). The soil at the experiment field was the black steppe soil, with the humus content in the soil layer $0-20 \mathrm{~cm}$ of $3.5 \%$ and the $\mathrm{pH}$ of the soil solution from 6.8 to 7.0.

The sunflower was grown in a rotation that included 12 fields. It was preceeded by winter wheat. After winter wheat harvest, the field was prepared by the method of improved land cultivation or soil tillage in layers. Conventional plowing method was applied in primary tillage. The depth of conventional plowing was $27-30 \mathrm{~cm}$. The conventional plowing was executed on October 1 . After that, the soil was leveled with a cultivator. Seedbed preparation and sunflower sowing at the depth of $6-8 \mathrm{~cm}$ were performed in the spring.

The sunflower hybrids Zaporozhskiy 9 and Kharkovskiy 58 and the varieties Lider and Prometey were sown at the row spacings of 70 and $15 \mathrm{~cm}$. Sunflower sowing was performed when the soil temperature at the depth of 6-8 $\mathrm{cm}$ reached 8$10^{\circ} \mathrm{C}$. Before harvest, the sunflower hybrids Zaporozhskiy 9 and Kharkovskiy 58 and the variety Prometey grew at the plant densities of 45, 55, <65,000 plants/ha, respectively, the variety Lider at the densities 45 and 55 thousand/ha.

Each variant of the experiment was made in four replicates. The experiment was harvested with a combine harvester „Sampo 500“.

Observations were executed in accordance with generally accepted methods, on 20 plants from inner rows of two nonadjacent replicates in each variant.

Leaf index was defined as a relation between leaf area per plant and crop area. Net photosynthesis (PPhP) of sunflower plants was calculated during the period 
head formation-head flowering, as a relation of 24-hour increase of dry matter weight of plants to leaf area.

\section{RESULTS AND DISCUSSION}

The accumulation of dry matter in plant of the sunflower hybrids and varieties was uneven during growing season and it depended on development stage, plant fresh matter, and agrotehnical conditions during cultivation. At the stage of flowering, the dry matter level in sunflower plants was found to increase with plant density. The rise of plant density to 55 and $<65,000$ plants/ha increased the dry matter level at the flowering stage at the hybrid Zaporozhskiy 9 by $11.5-11.7 \mathrm{~g} / \mathrm{plant}$ in the row spacing of $70 \mathrm{~cm}$ and by 4.4-6.7 g/plant in the row spacing of $15 \mathrm{~cm}$. The respective increases were 9.4-11 g/plant and 3.3-3.9 g/plant in the hybrid Kharkovskiy 58, $5.2 \mathrm{~g} /$ plant and $4.9 \mathrm{~g} /$ plant in the variety Lider, and $2.8 \mathrm{~g} /$ plant and $3.6 \mathrm{~g} /$ plant in the variety Prometey.

In the hybrids Zaporozhskiy 9 and Kharkovskiy 58, dry matter accumulation in the plant was more intensive in the row spacing of $70 \mathrm{~cm}$ than in the row spacing of $15 \mathrm{~cm}$. The varieties Lider and Prometey had practically the same level of dry matter accumuation in the row spacings of 70 and $15 \mathrm{~cm}$.

However, the row spacing of $15 \mathrm{~cm}$ provided the highest level of dry matter accumulation at the flowering stage. These levels were 8.7-15.8 g/plant in the hybrid Zaporozhskiy 9, 15.1-23.1 g/plant in the hybrid Kharkovskiy 58, 18.2-20.5 g/plant in the variety Lider, and 8.9-10.9 g/plant in the variety Prometey.

The increase of crop density reduced the leaf area per plant at the flowering stage of the hybrid Zaporozhskiy 9 by $6.2-15.6 \mathrm{dm}^{2}$ in the row spacing of $70 \mathrm{~cm}$ and by 4.6-13.6 $\mathrm{dm}^{2}$ in the row spacing of $15 \mathrm{~cm}$ (Table 1). The reduction of leaf area per plant in the agrophytocoenoces with the row spacing of $15 \mathrm{~cm}$ was less extensive in the hybrid Kharkovskiy 58 and the variety Prometey: 3.5-5.6 dm $\mathrm{dm}^{2}$ and 1.3-5.0 $\mathrm{dm}^{2}$, respectively. The leaf area of the variety Lider behaved differently. The plants of this variety in the agrophytocoenoses with the row spacing of $70 \mathrm{~cm}$ reduced the leaf area per plant by $9.3 \mathrm{dm}^{2}$ and in the agrophytocoenoses with the row spacing of $15 \mathrm{~cm}$ increased the leaf area per plant by $3.3 \mathrm{dm}^{2}$ when crop density was increased from 45 to 55 thousand/ha.

In the row spacing of $15 \mathrm{~cm}$, in all densities, the hybrids Zaporozhskiy 9 and Kharkovskiy 58 provided higher leaf area per plant by 3.5-5.6 $\mathrm{dm}^{2}$ and 3.1-7.0 $\mathrm{dm}^{2}$, respectively, than in the row spacing of $70 \mathrm{~cm}$.

However, in the agrophytocoenoses with the row spacing of $15 \mathrm{~cm}$, the varieties Lider and Prometey reduced the leaf area per plant at flowering stage by $5.1 \mathrm{dm}^{2}$ and 5.1-12.3 $\mathrm{dm}^{2}$, respectively.

Photosynthetic activity of the sunflower hybrids and varieties was determined by the same factors: leaf area and dry matter accumulation. At flowering stage, the 


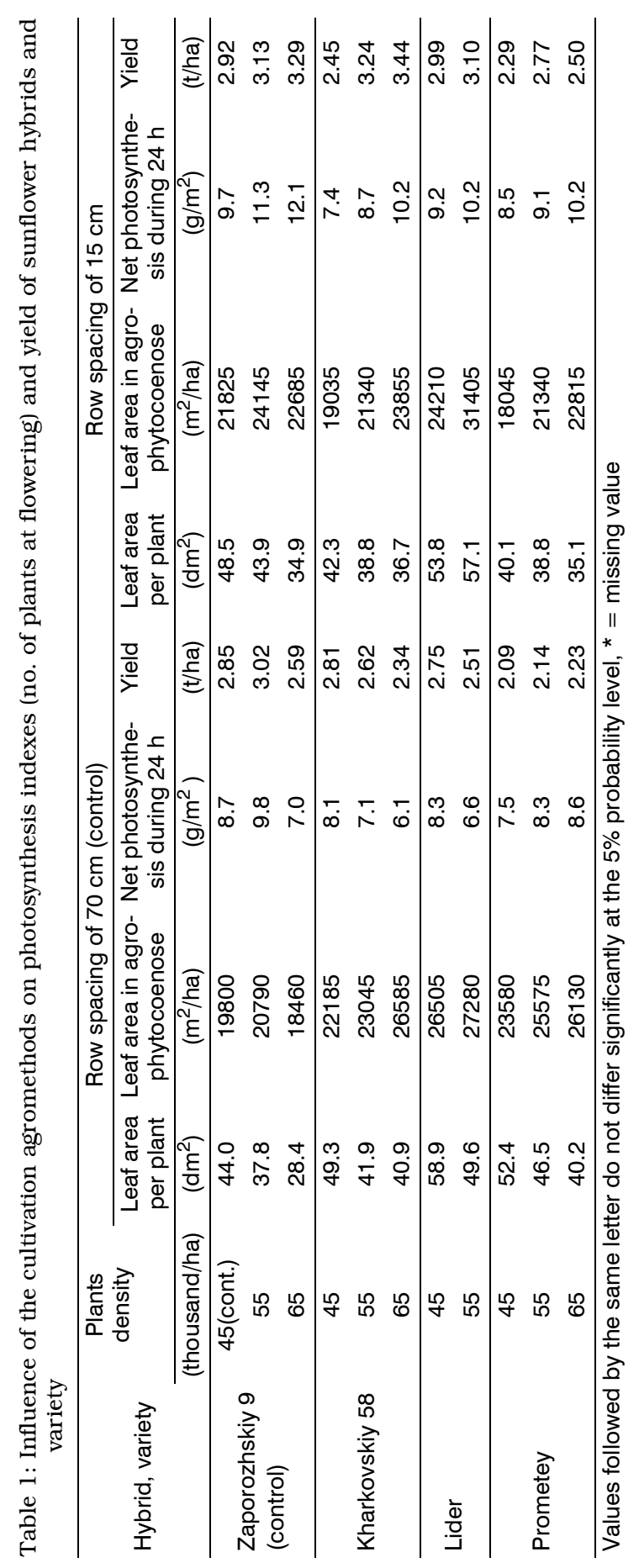


hybrid Zaporozhskiy 9 formed maximum leaf areas of 20,790 and $24,145 \mathrm{~m}^{2}$ /ha in the variant of plant density of 55 thousand/ha. The increase of plant density in the agrophytocoenosis to $<65,000$ plants/ha reduced the leaf area to $18,460 \mathrm{~m}^{2} / \mathrm{ha}$ in the row spacing of $70 \mathrm{~cm}$ and to $22,685 \mathrm{~m}^{2} /$ ha in the row spacing of $15 \mathrm{~cm}$. In the hybid Kharkovskiy 58, the increase of plant density to $<65,000$ plants/ha did not compensate the reduction of leaf area per plant. In the row spacing of $70 \mathrm{~cm}$, the hybrid Zaporozhskiy 9 had the maximum net photosynthesis during 24 hours of $9.8 \mathrm{~g} / \mathrm{m}^{2}$ in the plant density of 55 thousand/ha. The increase of plant density to $<65,000$ plants/ha reduced the net photosynthesis during 24 hours to $7.0 \mathrm{~g} / \mathrm{m}^{2}$. In the row spacing of $15 \mathrm{~cm}$, the hybrid Zaporozhskiy 9 increased the net photosynthesis during 24 hours from 9.7 to $12.1 \mathrm{~g} / \mathrm{m}^{2}$ as the plant density increased from 45 to $<65,000$ plants/ha. The reduction of leaf area to $22,685 \mathrm{~m}^{2} /$ ha did not reduce the net photosynthesis of this hybrid. In the row spacing of $15 \mathrm{~cm}$, the hybrid Zaporozhskiy 9 in increased the leaf area by 2,025-4,225 $\mathrm{m}^{2}$ /ha and the net photosynthesis during 24 hours by $1.0-5.0 \mathrm{~g} / \mathrm{m}^{2}$.

In the hybrid Kharkovskiy 58, the rise of plant density increased the leaf area by $860-4,400 \mathrm{~m}^{2} /$ ha in the row spacing of $70 \mathrm{~cm}$ and by $2,305-4,820 \mathrm{~m}^{2} / \mathrm{ha}$ in the row spacing of $15 \mathrm{~cm}$. However, in the same hybrid, these increases in leaf area reduced the net photosynthesis during 24 hours by $1.3-2.8 \mathrm{~g} / \mathrm{m}^{2}$ with the row spacing of $70 \mathrm{~cm}$. In the row spacing of $15 \mathrm{~cm}$, the hybrid Kharkovskiy 58 reduced the leaf area by $1705-3150 \mathrm{~m}^{2}$ /ha (all plant densities) and the net photosynthesis during 24 hours by $0.7 \mathrm{~g} / \mathrm{m}^{2}$ (in the plant density of 45 thousand/ha). In the same row spacing, the hybrid Kharkovskiy 58 increased the net photosynthesis during 24 hours to maximum indexes of $8.7-10.2 \mathrm{~g} / \mathrm{m}^{2}$ in the plant densities of 55 and $<65,000$ plants/ha and leaf areas of 21,340 and $23,855 \mathrm{~m}^{2} /$ ha.

The plant density rise from 45 to 55 thousand/ha in the agrophytocoenoses of variety Lider increased the leaf area by $775 \mathrm{~m}^{2} /$ ha in the row spacing of $70 \mathrm{~cm}$ and by $7195 \mathrm{~m}^{2} /$ ha in the row spacing of $15 \mathrm{~cm}$. The reduced index of net photosynthesis during 24 hours in the agrophytocoenoses with the row spacing of $70 \mathrm{~cm}$ by 1.7 $\mathrm{g} / \mathrm{m}^{2}$ is the result of increased plants density and leaf area. Conversely, the net photosynthesis during 24 hours is increased on $1.0 \mathrm{~g} / \mathrm{m}^{2}$ by the increases of plant density and leaf area. In the agrophytocoenoses with the row spacing of $15 \mathrm{~cm}$, the variety Lider increased the net photosynthesis during 24 hours by $0.9-3.6 \mathrm{~g} / \mathrm{m}^{2}$. A more intensive rise of photosynthetic productivity was registered by increased of plant density.

In the variety Prometey, the rise of plant density from 45 to $<65,000$ plants/ha increased the leaf area and the net photosynthesis during 24 hours by 1,995-2,550 $\mathrm{m}^{2} / \mathrm{ha}$ and $0.8-1.1 \mathrm{~g} / \mathrm{m}^{2}$ in the row spacing of $70 \mathrm{~cm}$ and by $3,295-4,770 \mathrm{~m}^{2} / \mathrm{ha}$ and $0.6-1.7 \mathrm{~g} / \mathrm{m}^{2}$ in the row spacing of $15 \mathrm{~cm}$. The growing of the variety Prometey in the agrophytocoenoses with the row spacing of $15 \mathrm{~cm}$ reduced the leaf area by 3,315$5,535 \mathrm{~m}^{2} /$ ha and increased the net photosynthesis during 24 hours by $0.8-1.6 \mathrm{~g} / \mathrm{m}^{2}$ as the result of more intensive accumulation of dry matter. 
In the agrophytocoenoses with the row spacing of $70 \mathrm{~cm}$, the net photosynthesis of the hybrid Zaporozhskiy 9 is determined by plant agrophytocoenosis at the plant density of 55 thousand/ha, but it is determined by individual plants in the agrophytocoenosis at the plant density of $<65,000$ plants/ha. In the agrophytocoenoses with the row spacing of $15 \mathrm{~cm}$, the productivity of photosynthesis is determined by individual plants of the agrophytocoenosis, irrespective of plant density.

In the agrophytocoenoses with the row spacing of $70 \mathrm{~cm}$, the net photosynthesis of the hybrid Kharkovskiy 58 and the variety Lider is determined by individual plants (reduction of leaf area per plant due to a simultaneous increase of leaf area of the agrophytocoenosis and dry matter content of sunflower plants per $1 \mathrm{~m}^{2}$ ). However, in the agrophytocoenoses with the row spacing of $15 \mathrm{~cm}$, their net photosynthesis is determined by plant agrophytocoenosis.

The net photosynthesis of the variety Prometey is determined by plant agrophytocoenosis.

In the agrophytocoenoses with the row spacing of $70 \mathrm{~cm}$, the increase of plant density from 45 thousand/ha to 55 thousand/ha raised the yield of the hybrid Zaporozhskiy 9 by 0.17 t/ha. The increase of plant density to $<65,000$ plants/ha produced the minimum yield of $2.59 \mathrm{t} / \mathrm{ha}$. In the agrophytocoenoses with the row spacing of $15 \mathrm{~cm}$, the plant density of 45 thousand/ha produced the yield of $2.92 \mathrm{t} /$ ha, which is similar to the yield obtained with the same plant density and the row spacing of $70 \mathrm{~cm}$. The rise of plant density to 55 and $<65,000$ plants/ha in the agrophytocoenoses with the row spacing of $15 \mathrm{~cm}$ increased the hybrid yields to 3.13 and $3.29 \mathrm{t} / \mathrm{ha}$, respectively.

The reaction of the hybid Kharkovskiy 58 to row spacing and plant density, as represented through yield forming, was different from that of the hybrid Zaporozhskiy 9 . In the agrophytocoenoses with the row spacing of $70 \mathrm{~cm}$, the hybrid Kharkovskiy 58 reduced the yield by $0.19-0.47$ t/ha as the plant density increased to 55 and $<65,000$ plants/ha. In the agrophytocoenoses with the row spacing of $15 \mathrm{~cm}$, the hybrid Kharkovskiy 58 reduced the yield level to 2.45 t/ha with the plant density of 45 thousand/ha. In the same row spacing, yield increase was registered only by the rise of plant density to 55 and $<65,000$ plants/ha. In these densities the hybrid produced the yields of 3.24 and $3.44 \mathrm{t} / \mathrm{ha}$, respectively. The maximum yield of the hybrid Kharkovskiy 58, $3.44 \mathrm{t} / \mathrm{ha}$, was achieved in the plant density of $<65,000$ plants/ha.

In the agrophytocoenoses with the row spacing of $15 \mathrm{~cm}$, the variety Lider reduced the yield by $0.24 \mathrm{t} / \mathrm{ha}$ as the plant density increased from 45 to 55 thousand/ha. Growing in the agrophytocoenose with conducted the yield increases of 0.24-0.35 t/ha were registered for the variety Lider in the row spacing of $15 \mathrm{~cm}$. The maximum yield of the variety Lider, 3.10 t/ha, was obtained with 55 thousand/ha.

In the agrophytocoenoses with the row spacing of $70 \mathrm{~cm}$, the variety Prometey produced the maximum yield of 2.23 t/ha with the plant density of $<65,000$ plants/ ha. In the agrophytocoenoses with the row spacing of $15 \mathrm{~cm}$, the variety Prometey 
had the highest yield of $2.77 \mathrm{t} /$ ha with the plant density of 55 thousand/ha, while the increase to $<65,000$ plants/ha resulted in yield reduction to $2.5 \mathrm{t} / \mathrm{ha}$.

The mathematical analysis of the data showed the following results. Yield performance of the hybrid Zaporozhskiy 9 was determined to a considerable extent by leaf area $(r=0.87)$ and net photosynthesis $(r=0.99)$. Direct positive correlations existed between the yield on one side and these indexes on the other. Yield performance of the hybrid Kharkovskiy 58 was determined only by net photosynthesis $(\mathrm{r}=0.95)$. The yield of this hybrid was not influenced by leaf area, as indicated by the negative correlation coefficient, $r=-0.04$. Yield performances of the varieties Lider and Prometey were determined by dry matter content in the plant and net photosynthesis. The variety Lider was more responsive. Its correlation coefficients between yield on one side and dry matter content and net productivity photosynthesis on the other were $r=0.89$ and $r=0.99$, respectively. In the case of the variety Prometey, the respective correlations were significant, amounting to $r=0.79$ and $\mathrm{r}=0.71$. Leaf area did not influence yield forming in the sunflower varieties. The correlation coefficients between the yield and leaf area in the varieties Lider and Prometey were $r=0.25$ and $r=-0.33$, respectively.

\section{CONCLUSION}

The growing conditions determined the yield level of the sunflower hybrids and varieties. The application of combined agrotechnical methods had different effects on photosynthetic indexes and yield forming of the studied sunflower hybrids and varieties. Manipulating agrotechnical methods (row spacing, plant density) allowed to control the growth and development of the sunflower hybrids and varieties and to influence the intensity of photosynthesis and yield level of the hybrids and varieties. Agrotechnical methods should help the sunflower agrophytocoenosis to maximize the most responsive indexes. In the case of the hybrid Zaporozhskiy 9 those were leaf area and net photosynthesis; in the case of the hybrid Kharkovskiy 58 this was net photosynthesis; in the case of the varieties Lider and Prometey those were dry matter content per plant and net photosynthesis.

\section{REFERENCES}

Bukov, O.D. and Zelenskiy, M.I., 1982. Photosynthesis and productivity of agricultural crops. Agricultural Biology 17(1): 14-27.

Demolon, A., 1970. Growth and development of cultivated plants. Science, Moscow, pp. 250. Dyakow, A.B. and Perestova, T.A., 1975. Morphology and anatomy of sunflower. In: Sunflower, Kolos, Moscow, pp. 21-29.

Gulaev, B.I., 1988. Pathways of increase of crop photosynthetic productivity. In: Photosynthesis and Productivity Process. Science, Moscow, pp. 218-222.

Nettevich, E.D., 1986. Culture of field and breeding. In: Grain Yield of Unchernozems. Kolos, Moscow, pp. 22-38.

Redko, V.V., 1985. Connexion between fast ripening of sunflower hybrids and productivity in conditions of insufficient humidity in southern steppe of Ukraine. In: Problems of 
Sunflower Breeding and Seed Production for Dry Steppe Conditions. VSGI, Odessa, pp. 25-31.

Vasilev, D.S., 1990. Sunflower. Agropromizdat, Moscow, pp. 4-121.

Zhuchenko, A.A., 1988. Adaptivity potential of cultivated plants. Shtiintsa, Kishinyov, pp. 326.

Zhuchenko, A.A., 1990. Ecology-genetic problems of plant breeding. Agricultural Biology 3: 323.

\title{
INFLUENCIA DE LAS MEDIDAS AGROTÉCNICAS EN EL ÍNDICE DE FOTOSÍNTESIS Y RENDIMIENTO DE GIRASOL
}

\author{
RESUMEN
}

La actividad fotosintética es el factor decisivo de incremento del rendimiento de girasol. Esta actividad determina la aplicación de las medidas agrotécnicas como son: la distancia entre filas y la densidad de las plantas. Los experimentos han demostrado que las medidas agrotécnicas posibilitan el control de crecimiento, crecimiento y rendimiento en los híbridos y variedades de girasol. La distancia entre filas y la densidad de las plantas, influyen en el índice de fotosíntesis y el rendimiento de agrofitocenosis de girasol. El cultivo de girasol con la distancia entre filas de $15 \mathrm{~cm}$ y diferentes variantes de densidad de plantas, ha incrementado el rendimiento del híbrido Zaporozhskiy 9 por 0.11-0.70 t/ha, del híbrido Kharkovskiy 58 por 0.62-1.1 t/ha, de la variedad Lider por 0.24-0.59 t/ha y de la variedad Prometey por 0.20-0.63 t/ha, en relación con el cultivo en agrofitocenosis con distancia entre filas de $70 \mathrm{~cm}$.

\section{EFFET DES MESURES AGROTECHNIQUES SUR L'INDICE DE PHOTOSYNTHËSE ET LE RENDEMENT DU TOURNESOL}

\author{
RÉSUMÉ
}

L'activit photosynthétique est le facteur décisif de l'augmentation du rendement dans le tournesol. Cette activité détermine l'application de mesures agrotechniques comme la distance entre les rangs et la densité des plantes. Des expériences ont prouvé que des mesures agrotechniques permettent de contrôler la croissance, le développement et le rendement des hybrides et des variétés de tournesol. L'espace entre les rangs et la densité des plantes affectent l'indice de photosynthèse et le rendement d'agrophytocénoses de tournesol. La culture du tournesol avec un espace entre les rangs de $15 \mathrm{~cm}$ dans différentes variantes de densité des plantes a augmenté le rendement de l'hybride Zaporozhskiy 9 de 0.11-0.70 t/ha, de l'hybride Kharkovskiy 58 de 0.62-1.1 t/ ha, de la variété Lider de 0.24-0.59 t/ha, de la variété Prometey de 0.20-0.63 t/ ha comparativement à la culture en agrophytocénoses avec un espace entre les rangées de $70 \mathrm{~cm}$. 